\title{
Thermal Performance Assessment of Shipping Container Architecture in Hot and Humid Climates
}

\author{
Ghada Mohammad Elrayies" \\ \# Department of Architecture and Urban Planning, Faculty of Engineering, Port Said University, Port Said, 42526, Egypt \\ E-mail: ghadaelrayies@eng.psu.edu.eg
}

\begin{abstract}
The reuse of shipping containers (SCs) in architecture has grown in popularity worldwide. However, few studies have focused on the thermal performance of buildings constructed with the use of refurbished SCs in hot and humid climates. This paper intends to (1) present a foundation for the understanding of environmental issues related to container-based buildings (CBBs) and (2) assess the thermal performance of CBBs in Port Said, a hot and humid region. To meet those targets, this paper first highlights the literature concerning such construction systems to identify gaps in related research areas. Second, this paper presents a comparative analysis of six simulation models, including a conventional building as a base model, an uninsulated SC, and four externally insulated SCs with four different thermal insulation materials: rock wool, wool, closed-cell spray polyurethane foam (ccSPF), and straw. The paper concludes that thermal insulation is irreplaceable in SCs reused as habitable spaces and that the most compatible thermal insulation for CBBs in the hot and humid climate of Port Said is ccSPF. Whereas straw performs more effectively than ccSPF as a cooler in the summer, it performs less effectively as a heater in the winter.
\end{abstract}

Keywords - Cargotecture, shipping container architecture, container-based buildings, hot and humid climates, Port Said, prefabricated buildings, Ecotect

\section{INTRODUCTION}

Over the past two decades, the trade imbalance between Asia and Europe on one side and North America on the other has been the main cause of the abundance and relative cheapness of shipping containers (SCs), as such containers carry manufactured goods to North America from Asia and, to a lesser extent, from Europe. Instead of ship empty containers back to Asia and Europe at considerable expense, manufacturing new containers is considered more economic. Once these containers have served their purpose, they are thus stored at seaports in large numbers before they are recycled as scrap or reused as spatial modules in architecture [1-6].

The Reuse of SCs for architectural purposes is not limited to certain types of buildings but extends from small private homes to skyscrapers. SCs offer infinite possible assemblies based on their modularity [7] and are used for all types of buildings, social, domestic, and commercial [8]. The SC goes a step further compared to traditional masonry, with longer cantilevers originating from its structural composition. As a relatively untapped trend, SCs can be slotted into a structure, and this integration creates a new symbiosis [8].

\section{A. Shipping Container Architecture (SCA) in Egypt}

Port Said and East Port Said are considered the most significant Egyptian ports, being located at the entrance of the Suez Canal, the largest international shipping channel and the crossroads of the most important world sea trade route between the East and the West [9]. East Port Said is one of the top fifty container ports in the world, ranked forty-first in 2015 [10]. SC handling, transport and storage are the main activities of the Port Said Container and Handling Company (PSCHC) at Port Said and the Suez Canal Container Terminal (SCCT) at East Port Said [11, 12]. The magnitude of the container handling industry in Port Said coupled with the lack of companies in the SC market in Egypt is the primary motivation for this research, which aims to encourage CBB construction in Port Said and in Egypt. Qubix Studios, founded by Karim Rafla and Youssef Farag, has just initiated the first steps regarding CBB construction in Egypt [13]. Figure 1-a illustrates the first CBB in Beni Suef, Egypt. The term "cargotecture" may be uncommon in Egypt to date, as CBBs in Egypt are rare, limited to military use as barracks and as public bathrooms, portable lounges, and entertainment marketplaces on beaches, as in figure 1-b. This limited use may stem from a lack of knowledge and skill in this type of construction and an ignorance of the effectiveness of SCs in ensuring a comfortable indoor environment in the warm climate of the humid tropics of Egypt. This, of course, has led to an 
absence of $\mathrm{CBB}$ construction qualifications in building bylaws and regulations.

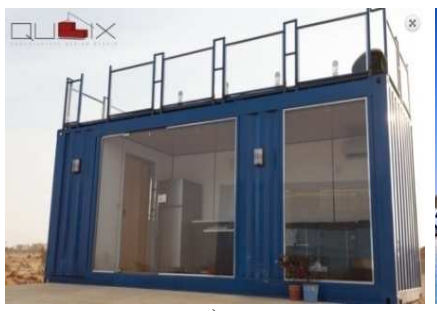

a)

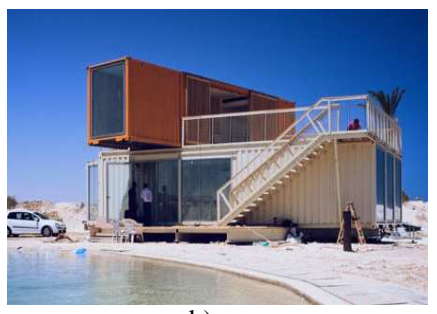

b)
Fig.1 (a) A private home constructed by Qubix Studios in Beni Suef, Egypt [14]. (b) A container lounge in Hacienda , North Coast, Egypt [15]

\section{MATERIAL AND METHOD}

Port Said is among the most important ports handling shipping containers in Egypt. The existence of a surplus of SCs in ports necessitates a rethinking regarding their reuse for other purposes, particularly in architecture. Since research on the environmental performance of SCs in hot and humid climates is scarce, this paper aims to (1) achieve a comprehensive understanding of the environmental issues related to SCs and their contribution to reducing the effects of climate change issue and (2) evaluate the thermal performance of CBBs in the hot and humid climate of Port Said. For this purpose, this paper has conducted an analytical comparison between six simulation models: the first base model is a traditional brick masonry building, the second is an uninsulated SC, and the other four models are SCs insulated with externally selected thermal insulation materials based on prior literature. Ecotect has been used as an environmental simulation program to evaluate the thermal performance of these CBB models. The paper has adopted two main approaches: The first is to evaluate the existing literature dealing with environmental issues related to CBB construction on a global scale, and the second is to conduct a simulation study aided by Ecotect.

\section{A. Literature Review}

\section{1) The Green Aspect of CBB :Mixed Literature}

The reuse of SCs for construction purposes has increased dramatically in recent times as green alternative. However, findings have diverged regarding the sustainability of CBBs. Reference [16] has pointed to SCs as ecofriendly and costeffective modules [16]. Achieving sustainability through the shipping container architecture (SCA) comes from "upcycling", which means obtaining a higher-quality product with few modifications [17]. The contribution of CBBs in sustainability is thus attributed to reusing and recycling, which reduce embodied energy, carbon footprints, steel waste, and harmful greenhouse gas emissions [1, 3, 4, 18]. For example, waste produced onsite by CBB construction is $70 \%$ less than that produced by traditional counterparts [1].

Reusing SCs for architecture also saves the energy otherwise consumed in melting and cutting them for conversion into decomposing landfill material, as the energy consumed in converting the container into a building is negligible compared to the energy consumed in converting it into scrap [1].
However, it is impractical to generalize the sustainability of SCs, since this varies according to their design. A feasibility study conducted by [17] has found that singlestory $\mathrm{CBBs}$ are ineffective and more costly compared to conventional counterparts, while three-story CBBs are feasible, less costly, three times faster in construction, and more environmentally effective than traditional counterparts [17].

Despite CBBs being integrated construction systems and prefabricated modules, they surpass prefabs in their upcycling capability, as prefabs consume energy in the manufacturing process.

Additionally, CBBs, like conventional buildings, can be provided with green technologies as off-grid constructions. Many real-world CBBs testify to this possibility, such as the 2010 Shipping Container House in Nederland, Colorado, by Studio H: T [19].

Regarding lifecycle environmental analysis, [17] concluded through a construction phase lifecycle analysis that $\mathrm{CBBs}$ have a smaller environmental impact than their conventional counterparts, and this was attributed to upcycling. Reference [1] pointed out that the operation phase of $\mathrm{CBB}$ construction has the predominant lifecycle impact, except for water use and solid waste generation, with an advance age of one hundred years potentially increasing the effects of the whole life cycle [1].

$\mathrm{CBBs}$ also represent a gateway to a new market in light of the current economic crisis [3]. They are considered a flexible choice, particularly for economically depressed countries with great social needs, unskilled workers, a lack of building materials, and a lack of tools and funding necessary for the construction process [8]. CBBs also meet a need for emergency interim housing and post-disaster housing, as well as shelters for the homeless, particularly in developing countries and in disaster relief situations [5, 19, 20]. Furthermore, CBBs provide a solution to land shortages by allowing construction upon existing buildings or unused buildings, as evidenced by the shipping container residences at Mill Junction in Johannesburg, constructed upon unused grain silos [19].

Although the reuse of SCs for building purposes seems to be a green and sustainable solution, researchers have raised concerns regarding sustainability due to the energy required to make SCs habitable, particularly with regard to thermal performance, incremental costs, and construction difficulties [1]. The energy required to make SCs habitable is represented in the processes of sandblasting, window cutting, replacing floors, and consuming fuel in transportation, which impacts the environmental footprint of construction [20]. Moreover, other studies have shown that a reduction in embodied energy among CBBs is uncertain due to the energy consumed in steel welding and cutting. A study conducted by Olivares (2010) pointed out that CBBs consume more energy and release more carbon than traditional counterparts [4]. Reference [21] has indicated through a study of Austrian CBB classrooms that the indoor environmental performance of CBBs is a little less than their conventional counterparts. Additionally, carbon dioxide concentration measurements have indicated that the concentration of $\mathrm{CO}_{2}$ in $\mathrm{CBBs}$ is higher than in conventional 
buildings. However, this may be attributed to the high occupancy rates of CBBs.

\section{2) Types of SCs}

SCs for construction are also called intermodal steel building unit modules (ISBU) [1, 4, 22, 23]. Notably, SCs are divided into two types, maritime and domestic. Maritime SCs are those primarily manufactured for use on ships and in logistics, and these can be stacked up to ten high. Domestic SCs are manufactured for domestic purposes and can be stacked only to three high. The advent of domestic SCs stemmed from an increasing demand for SCs that was not equivalent to supply [22]. Moreover, while maritime SCs are not constructed according to building codes [1], both types should conform to ISO standards, as both are used as ISBU modules [22]. The Transformation of SCs into CBBs is not limited to undamaged SCs. Superficially damaged containers are also valid for construction purposes, as designers can choose damaged places for openings, cover damages with cladding, or replace damaged areas with new parts [8]. Among the different types of SCs available on the market, containers manufactured in accordance with ISO standards should be used for their geometrical and mechanical properties [3], and specifications of containers used for architectural purposes should thus conform to ISO standards [24].

\section{3) SC Specifications}

\section{Dimensions:}

The dimensions of SCs available in the market vary. Common dimensions used are 6.0, 9.0, and $12.0 \mathrm{~m}$ in length; 2.4, 2.55, and $2.7 \mathrm{~m}$ in height; and $2.4 \mathrm{~m}$ for width. For architectural purposes, SCs with a height of $2.7 \mathrm{~m}$, with a minimum clear ceiling height of $2.40 \mathrm{~m}$, are used where best suited in terms of their internal height. Such SCs are known as high cube (HC), with commercial names of $20^{\prime} \mathrm{HC}$ or $1 \mathrm{AAA}$, at a length of $6.0 \mathrm{~m}$, and $40^{\prime} \mathrm{HC}$ or $1 \mathrm{CCC}$, at a length of $12.0 \mathrm{~m} \mathrm{[3]}$ (Table I). 20'HC SCs are preferable compared to $40^{\prime} \mathrm{HC}$ for reuse as $\mathrm{CBBs}$ due to their better durability and lesser cost. In other words, a combination of two $20^{\prime} \mathrm{HC}$ containers is better than one $40^{\prime} \mathrm{HC}$ container [4].

\section{TABLE I}

20'HC AND 40'HC TECHNICAL STANDARDS

\begin{tabular}{|l|c|c|c|c|c|c|}
\hline \multirow{4}{*}{ Model } & \multicolumn{2}{|c|}{$\begin{array}{c}\text { Length }(\mathrm{m}) \\
(\text { lateral face })^{\mathrm{a}}\end{array}$} & \multicolumn{2}{c|}{$\begin{array}{c}\text { Width (m) } \\
\text { (door face, front } \\
\text { face }^{\mathrm{a}}\end{array}$} & \multicolumn{2}{c|}{ Height $(\mathrm{m})^{\mathrm{b}}$} \\
\cline { 2 - 8 } & $\begin{array}{c}\text { External } \\
\text { dim. }\end{array}$ & $\begin{array}{c}\text { Internal } \\
\text { dim. }\end{array}$ & $\begin{array}{c}\text { External } \\
\text { dim. }\end{array}$ & $\begin{array}{c}\text { Internal } \\
\text { dim. }\end{array}$ & $\begin{array}{c}\text { External } \\
\text { dim. }\end{array}$ & $\begin{array}{c}\text { Interna } \\
1 \text { dim. }\end{array}$ \\
\hline $20^{\prime} \mathrm{HC}$ & 6 & 5.9 & 2.4 & 2.34 & 2.89 & 2.71 \\
\hline $40^{\prime} \mathrm{HC}$ & 12.2 & 12 & 2.4 & 2.34 & 2.89 & 2.71 \\
\hline
\end{tabular}

${ }^{a}$ The difference between the external and internal dimensions is attributed to corrugation depth. For instance, for a $20^{\prime} \mathrm{HC}$, one must deduct $50 \mathrm{~mm}$ from the width of each short side and $30 \mathrm{~mm}$ from the width of each lateral face.

$\mathrm{b}$ The difference between the external and internal dimensions comes from the ceiling corrugation depth (about $25 \mathrm{~mm}$ ), flooring thickness $(28 \mathrm{~mm})$, and steel cross member depth $(127 \mathrm{~mm})$ for both $20^{\prime} \mathrm{HC}$ and $40^{\prime} \mathrm{HC}$ SCs. Sources: [3, 28, 29].

\section{Stacking:}

According to the literature, the maximum stacking capacity of SCs ranges between six when fully loaded and 12 when empty [1-4, 16, 25, 26]. However, [27] has claimed that there is no limit for vertical SC stacking; stacking simply requires structural design calculations for each case and appropriate reinforcement at the necessary points [27]. From real-life $\mathrm{CBBs}$ examples, it has been inferred that stacking ranges from one up to nine stories.

\section{Structure and Apertures:}

Most of SCs are made of weathering steel or corten steel, which ensures a high corrosion resistance $[3,8,26]$. (The exception is profile DCP which is made with SM50YA steel.) Construction includes the use of trapezoid metal sheets to form the walls, the ceiling, and the edges of the box, and a grid to support the wooden floor [3]. The thickness of the trapezoidal corten steel sheets for walls and ceiling is $2 \mathrm{~mm}$ $[3,4]$, and the depth of the corrugated steel sheets ranges between 25,30 , and $50 \mathrm{~mm}$, varying depending on SC model and surface [29]. Deep corrugation provides higher inertia and more rigidity [5]. The corners are designed as rigid elements to support the container and allow for connection between containers. The door is located on one of the smaller sides. The standard flooring in an ISO SC is $28 \mathrm{~mm}$ thick marine-grade plywood [3] (Figures 2 and3). Preparation of SCs for CBB construction should take place in a controlled factory environment. These processes include all preparatory work, such as disinfection, cleaning, cutting of door and window openings, creation of joints, surface preparation and painting, installation of networks, and completion of all necessary details to avoid problems on site. The containers are then transported to the construction site, ready and connected. The average lifespan of an SC is around fifteen years [3].

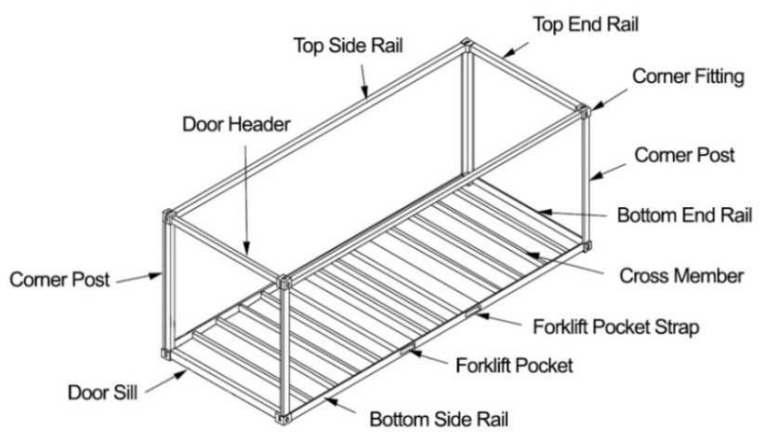

Fig.2 Primary structural components for a typical 20' ISO SC [30]

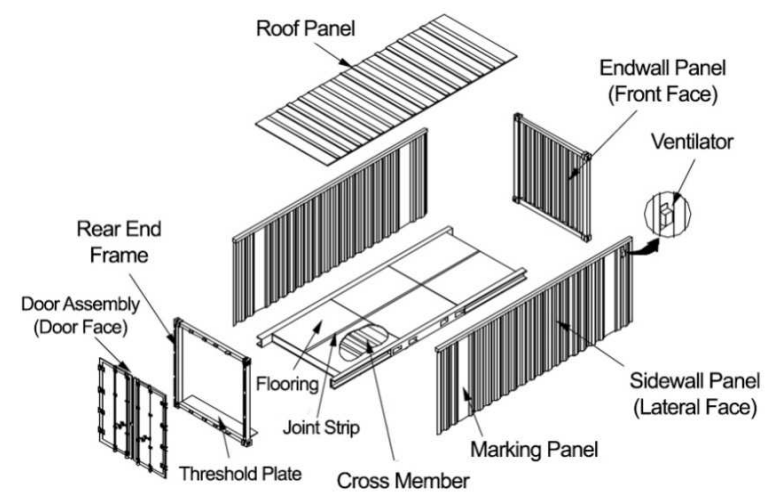

Fig.3 The core envelope of a typical 20' ISO SC [30] 
Cost:

Compared to traditional buildings, SCs are considered relatively cheap due to upcycling [2,16]. Reference [23] has pointed out that the cost of converting an SC into a building is less than that of constructing a conventional building, but increasing the interior space and the quality of interior finishes could lead to the same cost as a traditional building [23]. However, according to [7, 27], numerous exiting CBBs are far worse than their conventional counterparts, being less cost effective and not secure for habitation. If cost savings are achieved, the reduction may be only about $20 \%$ compared to conventional buildings, and this comes at the expense of human habitation considerations in terms of thermal and acoustic performance [7, 27]. The need for insulation materials, transportation, and installation may considerably elevate the cost of construction [4, 17]. Nevertheless, factors affecting a comparison between the cost of a conventional building and a CBB vary between (1) the availability of old stock containers; (2) new, old, and refurbished container prices; (3) traditional housing prices; (4) transportation and delivery prices, including crane systems; and (5) design space and vertical expansion, such as by staggering containers to increase space while reducing cost. As well, the vertical expansion of CBBs causes cost savings according to a comparison study conducted by [17] where in the cost of constructing a single-story SC exceeded the cost of a similar conventional house with the additional cost of thermal insulation and transportation. However, the cost of a multistory $\mathrm{CBB}$ is quite close to that of a singlestory conventional building [17].

The price of an old SC ranges between USD 1,200 and USD 1,600, and a new one does not exceed USD 6,000 [2, $17,25]$. In China, the cost of a new $20^{\prime} \mathrm{HC}$ SC ranges between USD 2,000 and USD 5,000, while the cost of a $40^{\prime} \mathrm{HC}$ SC ranges between USD 3,500 and USD 7,000. Naturally, costs vary from one country to another. However, certain factors affect the cost of old SCs: These are (1) the general condition of the container in terms of the extent of its need for maintenance; (2) the age of the container, as companies typically sell the container if its lifecycle exceeds ten years regardless of its physical condition; (3) the structural damage of the container, which reduces the selling price in case requiring high-cost reworks; (4) the model of the SC, such as when utilizing a $40^{\prime} \mathrm{HC}$ SC instead of a $20^{\prime} \mathrm{HC}$ would achieve cost savings and provide more space; and (5) the distance between the original site and the delivery location [17].

Table II shows the advantages and disadvantages of SCs in terms of issues related to their transformation into CBBs.

TABLE II.

PROS AND CONS OF SCS

\begin{tabular}{|c|c|}
\hline \multirow{4}{*}{ Pros } & 1. Strength and durability: SCs bear high loads and resist harsh environmental conditions $[3-5,18,23,25]$ \\
\hline & 2. Modularity: They allow flexibility in design $[1,4,16,17,23,25]$. \\
\hline & 3. Short construction time: They shorten construction times by $40 \%$ to $60 \%$ over conventional counterparts $[1,8,16,17]$. \\
\hline & 4. Simple foundations: SCs are simpler than traditional counterparts $[7,8,24,31,32]$. \\
\hline \multirow{8}{*}{ Cons } & $\begin{array}{l}\text { 1. Temperature and humidity: SCs require certain procedures to thermally insulate structural elements and to treat against } \\
\text { moisture }[1,16,23,25,27] \text {. }\end{array}$ \\
\hline & $\begin{array}{l}\text { 2. Contamination: Original SC coatings and wood flooring contain harmful chemicals which have to be treated if used in } \\
\text { CBBs }[1,20] \text {. }\end{array}$ \\
\hline & 3. Topography: CBBs fit perfectly flat sites. Sloped sites are inappropriate [4]; otherwise, certain procedures are required. \\
\hline & $\begin{array}{l}\text { 4. Structural reinforcement: The transformation of an SC into a CBB means a significant change in its load-bearing } \\
\text { capabilities; accordingly, it needs to be structurally strengthened }[4,7,8,17,27] \text {. }\end{array}$ \\
\hline & $\begin{array}{l}\text { 5. Acoustics: The high density of steel makes sound propagate quite easily, making SCs noisy, as does vertical stacking. This } \\
\text { indicates the need for acoustic insulation }[1,8,17] \text {. }\end{array}$ \\
\hline & $\begin{array}{l}\text { 6. Building permits: SCs have not been legislated in building codes so far, which may be attributed to the unfamiliar use of } \\
\text { steel for housing construction or for their unknown structural properties }[1,25] \text {. }\end{array}$ \\
\hline & $\begin{array}{l}\text { 7. Unpopularity: The unpopularity and rejection of CBBs may come from their external appearance. This reflects the } \\
\text { significant role of architectural design in fostering a pleasing aesthetic }[4,17,24] \text {. }\end{array}$ \\
\hline & 8. Skilled labor: CBB construction requires skilled labor, which may add to the cost $[1,4,23,25]$. \\
\hline
\end{tabular}

\section{4) Architectural Strategies for CBBs toward Sustainable Design}

CBBs, like conventional buildings, need an environmentally conscious design to comply with the principles of green architecture and sustainability. The architectural strategies that could fit SCs encompass various procedures, reviewed below.

Living roofs help reduce indoor temperatures on hot days by up to $8 \%$, according to [33]. Different roofing systems could be used, such as double roofing, which can act as thermal insulation, or reflective painted shed, hip, or gable roofing. This is contingent upon the design requirements and the budget [1]. Architectural treatments involve external shading and small windows with low-E glass and/or internal blinds [34] (Figure 4-e). A rooftop with photovoltaics (Figure 4-d) may provide all the energy necessary to operate the heating, cooling, and lighting systems in a CBB, as in the Greentainer project in Gandino, Italy [35]. Figure 4 indicates some architectural measures that contribute to the alleviation of the thermal loads on the SC body. One significant measure to passively ventilate $\mathrm{CBBs}$ is crawl space 
ventilation, which ensures the movement of air underneath an SC. However, certain types of foundations are suited to such ventilation systems, such as raised foundations (concrete piers). This type of ventilation protects against mold and rot and prevents moisture from leaking to the flooring. This type does not suite humid climates, however, as the external air is wetter. In that case, a dehumidifier as a mechanical ventilation tool is more suitable [36]. The next section reviews in detail the thermal insulation materials assigned for CBBs.

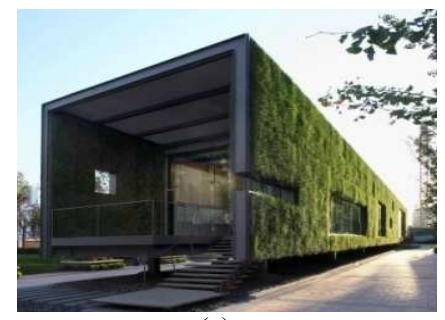

(a)

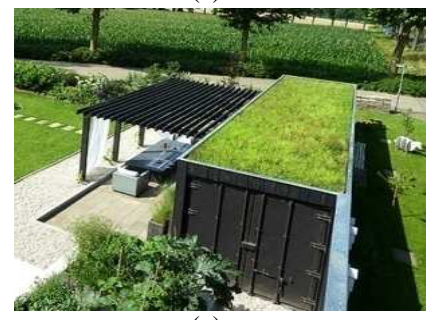

(c)

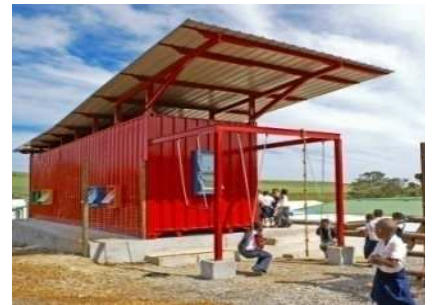

(e)

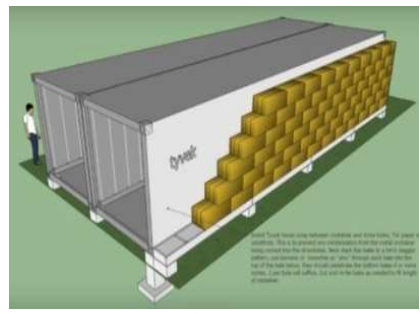

(b)

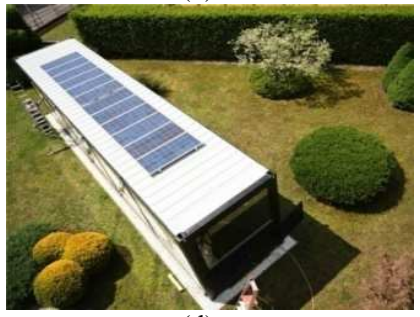

(d)

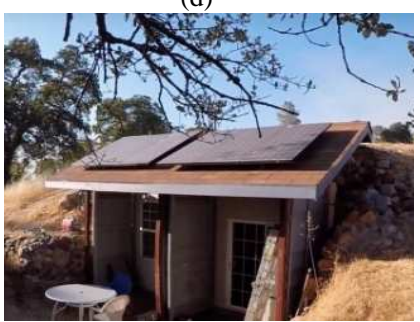

(f)
Fig.4. Architectural strategies towards green cargotecture (roof and wall insulation): (a) A steel structure with green walls [37]. (b) An SC with straw-bale walls [38]. (c) An SC with a green roof [39]. (d) An SC with solar cells [40]. (e) An SC with double roofing [41]. (f) An underground SC partially buried with earth [42]

\section{Thermal Insulation}

Although the reuse of SCs in architecture is promising, researchers have raised significant concerns with their suitability for different climates, as they are manufactured from steel, a material of high thermal conductivity. In tandem with their susceptibility to condensation, an environment of high humidity requires that SCs have thermal insulation and a ventilation system to ensure a comfortable indoor environment [4].

\section{Thermal Insulation compatible with CBBs:}

Diverse types of thermal insulations suit metal structures, such as spray foam, rigid insulation panels, blanket insulations such as rock wool and fiberglass, fibers such as rigid mineral wool, and ecofriendly insulation materials such as wool, recycled cotton, mud, and straw bales. Despite wool and cotton being ecofriendly insulation materials, they cause condensation and consequently result in corrosion. Likewise, mud is not recommended for rainy environments, as it works better in dry and hot climates.

Spray foam insulation ensures a smooth, seamless barrier, which helps prevent corrosion and mold. It is characterized by speed, flexibility, and a high R-value, signifying its resistance against heat flow. Its only disadvantage is its high cost. It can be applied on both internal and external walls as well as floors to prevent moisture. Foam could be painted directly to give the final finished look. Rigid insulation panels entail the installation of studs. Compared to blanket insulation, insulation panels are faster to install but might be more expensive. However, they have a high insulating value for their relatively small depth. Blanket rolls are the cheapest compared to foam insulation and insulation panels. They too require stud walls. The most common type of blanket insulation is rock wool, which may need more care in handling. If fiberglass is used, preventative measurements are necessary. Rigid mineral wool is fire resistant, with a melting point of about $2,000{ }^{\circ} \mathrm{F}$. It is also open to vapor, which allows moisture to dry and therefore protects against rust. As well, it is soundproof [33, 39, 43, 44].

External insulation is better than internal $[8,16]$ for two reasons. The first is because internal insulation reduces the internal dimensions of the container [8]. The second is that external insulation allows the architect to take full advantage of the container's thermal inertia. Furthermore, the insulation should be applied without metal or wood studs, as they act as cold bridges, creating a reduction in thermal insulation [16]. Internal insulation can be used if it has a thin depth, as with multilayer aluminum foil membrane insulation. In terms of cost, SCs themselves are waterproof. Thus, external thermal insulation requires adding waterproofing, which causes additional cost. Moreover, container stacking reduces the need for thermal insulation [8]. Table III illustrates some types of thermal insulations assigned to SCs.

\section{Thermal Performance of CBBs in Different Climates:}

\section{a) Cold climates:}

Reference [4] has indicated that CBBs are suitable for temperate and cold climates. Reference [8] has compared the U-value of four different models in the United Kingdom: (1) an uninsulated $20^{\prime} \mathrm{HC}$ SC, (2) an insulated SC with a standard insulator, (3) an internally insulated SC with Celotex, and (4) an externally insulated SC with Celotex. The results point to a considerable difference between the Uvalues, encompassing the roof, floor, and walls of the uninsulated SC and the insulated SCs in favor of the latter. Reference [21] has compared CBB classrooms with conventional classrooms in Austria, measuring temperature, humidity ratio, and carbon dioxide concentration. The results point to a rise in temperature in the coldest month (February) and an unexpected decrease in temperature in the relatively hottest month (June) in the CBBs. The researchers attributed this to the small windows and high shading due to obstructions around the CBBs. Relative humidity remained at normal levels. 
TABLE III

THERMAL INSULATION FOR METAL CONSTRUCTIONS SUGGESTED BY PRECEDENT STUDIES

\begin{tabular}{|l|l|l|}
\hline Insulator Type & Specifications & Reference \\
\hline $\begin{array}{l}\text { - Glass fiber mat. } \\
\text { - EPS. }\end{array}$ & $\begin{array}{l}\text { Botes has compared ISBU housing and conventional housing in a test case using a 100 mm } \\
\text { glass fiber mat, a 35mm EPS internal insulation and plaster coat finish for the ceiling, and a 35 } \\
\text { mm EPS internal insulation for the walls. }\end{array}$ & - [17] \\
\hline $\begin{array}{l}\text { - Foil board. } \\
\text { - Ceramic coating. }\end{array}$ & $\begin{array}{l}\text { A } 25 \mathrm{~mm} \text { layer of foil board attached to the SC's metal walls works as a thermal breaker, and } \\
\text { A ceramic coating as thermal insulation for steel surfaces can achieve tremendous energy } \\
\text { savings by preventing heat transfer. It can be used as paint, an adhesive, a thermal insulator, and } \\
\text { a noise barrier, and it is fire resistant. } \\
\text { Polyurethane foam works well as an internal insulator alongside the ceramic coating as an } \\
\text { external insulator, as that combination further reduces the carbon footprint. }\end{array}$ & - [1] \\
\hline - ccSPF & $\begin{array}{l}\text { Closed-cell spray polyurethane foam is best suited to CBBs as it is strong and durable. It } \\
\text { provides an extra sealing for openings and has waterproof resistance, high durability, a high R- } \\
\text { value (15.75), and renewability }\end{array}$ & - [5] \\
\hline - Prodex Total Insulation \\
(PTI). & $\begin{array}{l}\text { Prodex Total Insulation (PTI) is designed specifically for metal structures because it operates as } \\
\text { a thermal breaker, radiant heat barrier, and vapor barrier at the same time. This insulation } \\
\text { consists of aluminum foil with a polyethylene backing and a surrounding closed-cell } \\
\text { polyethylene foam. The R-value for PTI is 7 for walls and 15.67 for ceilings, with 5mm } \\
\text { thickness. }\end{array}$ & - [29] \\
\hline
\end{tabular}

\section{b) Hot and humid tropical climates}

A comparison study conducted between CBBs and traditional buildings in hot and humid tropical climates has found that SCs are not inferior to traditional buildings in terms of thermal insulation [18]. The existence of few studies on the thermal performance of SCs in different climates, particularly hot and humid climates, signifies a need for further research $[1,4]$

\section{B. Thermal Performance Assessment}

This paper aims to study the construction of CBBs in Port Said, Egypt, a hot and humid region. The software used is Ecotect. Since a weather file on Port Said is not available in Ecotect's library, the weather file of El Arish has been uploaded, as it is the closest to Port Said. (The latitudes of Port Said and El Arish are $31.2653^{\circ} \mathrm{N}$, $31.1321^{\circ} \mathrm{N}$ respectively.) To perform a comparison between a conventional building and a CBB in tandem with exploring the thermal performance of CBBs, this paper has assessed six models, all single-story one-zone buildings with two opposite windows on the two lateral faces (north and south) to ensure natural ventilation and a door on the door face. The dimensions of all models match those of 20'HC containers (Figure 5).

According to the literature and their individual properties, the insulation materials to be investigated in the assessment section were selected as follows: (1) ccSPF was selected for its high-R-value, moisture resistance, common use among steel structures, and renewability; (2) rock wool was selected because it is vapor open and sound and fire resistant; and (3) wool and straw were selected since they are ecofriendly materials (Figure 6). All insulation materials are assumed to be applied externally to take full advantage of the clear internal dimensions of the spaces. The thicknesses of the materials have been standardized to $100 \mathrm{~mm}$ in all models. The finishing materials vary according to each insulation material.

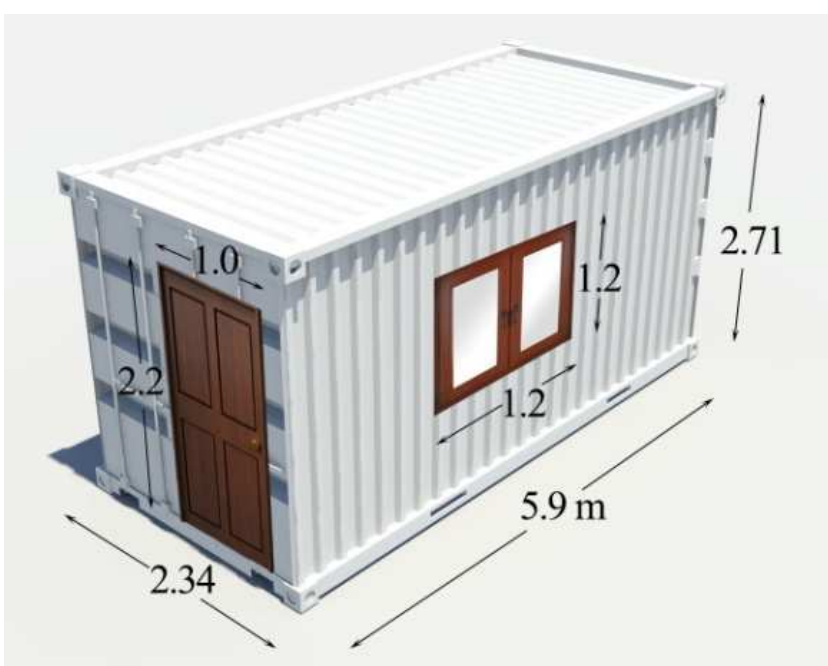

Fig.5 The clear internal dimensions of the six models are the same as those of a 20 'HC SC

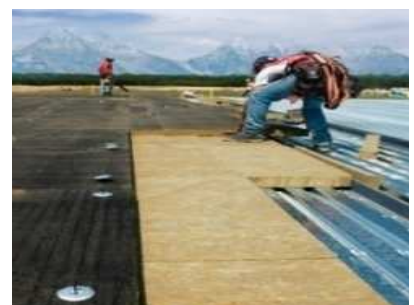

(a)

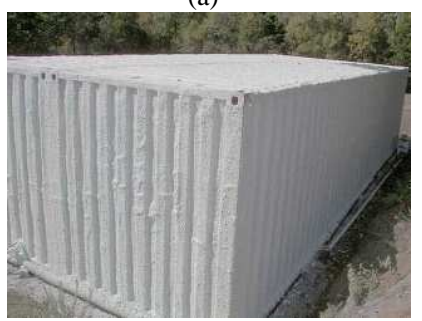

(c)

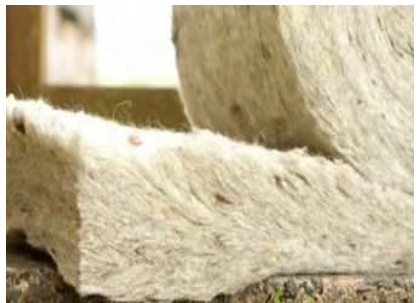

(b)

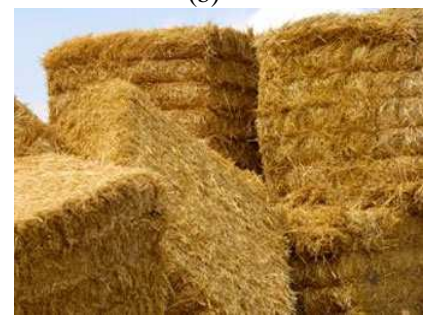

(d)
Fig.6 The suggested thermal insulation materials for model cases: (a) external rock wool insulation for Model 3 [45], (b) external wool for Model 4 [46], (c) external ccSPF for Model 5 [44], and (d) external straw for Model 6 [47] 
Model 1 is a traditional brick masonry building, Model 2 is an uninsulated $20^{\prime} \mathrm{HC}$ SC, Model 3 is an externally insulated $20^{\prime} \mathrm{HC} \mathrm{SC}$ with rock wool, Model 4 is an externally insulated $20^{\prime} \mathrm{HC}$ SC with wool, Model 5 is an externally insulated $20^{\prime} \mathrm{HC}$ SC with medium-density ccSPF, and Model 6 is an externally insulated $20^{\prime} \mathrm{HC}$ SC with straw boards. The flooring is standardized in models 2, 3, 4, 5 , and 6 , whereas the two windows and the door are standardized in all models. The detailed specifications are shown in Table IV. The thermal specifications of the materials that do not exist on Ecotect have been uploaded as shown in Table V.

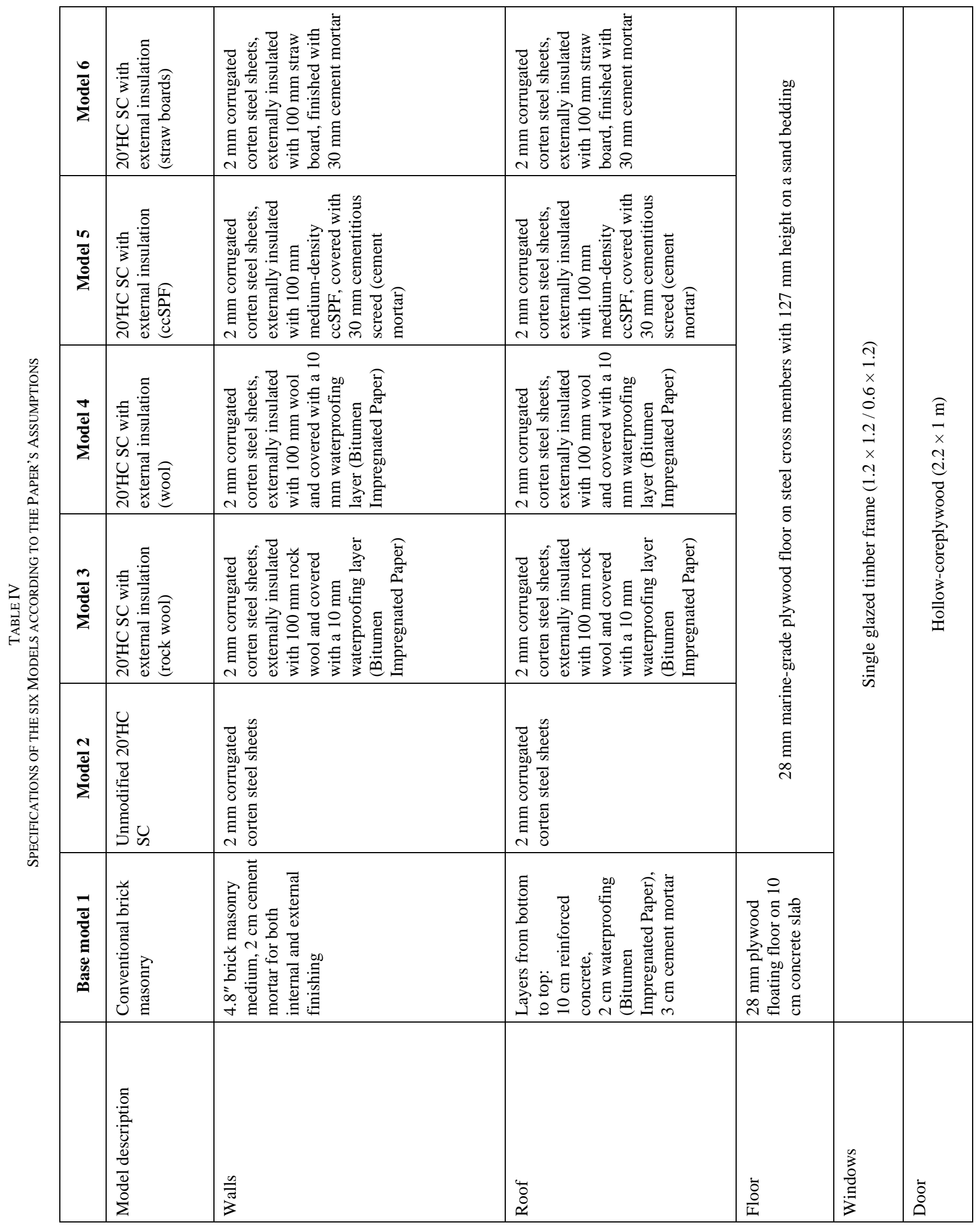


TABLE V

SPECIFICATIONS OF CORTEN STEEL (A) AND CCSPF

\begin{tabular}{|l|c|c|}
\hline & Corten steel (a) & (ccSPF) \\
\hline Thermal conductivity $(\mathrm{W} / \mathrm{m} . \mathrm{K})$ & $16\left(\right.$ at $\left.100^{\circ} \mathrm{C}\right)[48]$ & $0.024\left(\right.$ at $\left.50^{\circ} \mathrm{C}\right)[49]$ \\
\hline Density $\left(\mathrm{kg} / \mathrm{m}^{3}\right)$ & $8,000[48]$ & $33[50]$ \\
\hline Specific heat $(\mathrm{J} / \mathrm{kg} . \mathrm{K})$ & $500[48]$ & $1,674^{\mathrm{a}}$ \\
\hline
\end{tabular}

a This is similar to the specific heat of a polyurethane foamed-in-place rig according to Ecotect.

\section{RESULTS AND DISCUSSION}

\section{A. Hourly Temperature Profile (HTP) for the Hottest Day and the Coldest Day (Average)}

According to the HTP for the hottest day (average), April 30 (Figure 7), Model 1 (brick) heated the internal space from 10 p.m. to 9 a.m., during which time the inside temperature increased in a range between 0.5 and 5.4 degrees, while it cooled the internal space in the second half of the day, during which the difference between inside and outside temperatures ranged between 9 and 2.2 degrees. Model 2 (SC without insulation) heated the internal space all day long. The difference between inside and outside temperatures ranged between 6.5 degrees at 12 p.m. and 0.7 degrees at 7 p.m.

Model 3 (SC with rock wool) also heated the space but was better in cooling than Model 1 from 12 a.m. to 4 a.m. and from 9 a.m. to 10 p.m., when the difference between the inside and outside temperatures ranged between 10.5 and 2.9 degrees. Although it heated the internal space, it was better in cooling than was the traditional building. The thermal performance of Model 4 (SC with wool) was similar to that of Model 3 (SC with rock wool) to a large extent, in favor of Model 4. Model 5 (SC with ccSPF) also heated the space from 11 p.m. to 5 a.m. However, it was the lowest model in heating. Its cooling period, from 10 a.m. to 9 p.m., was better than the traditional building, but it was not the best model in cooling, being almost similar in cooling to Model 3 (SC with rock wool) and Model 4 (SC with wool).

Model 6 (SC with straw) was the best model in cooling, from 10 a.m. to 6 p.m., with a difference in temperature inside and outside of 11.4 degrees at 4 p.m. and 2.2 degrees at 9 p.m. However, it also heated the space from 10 a.m. to 9 a.m. A comparison between all models regarding cooling in the maximum temperature range outside, from 10 a.m. to 9 p.m., reveals that Model 6 is preferable where the maximum recorded temperature outside is $39.8{ }^{\circ} \mathrm{C}$. Ultimately, comparing between all models in terms of the best in cooling and worst in heating on the hottest day, Model 5 (SC with ccSPF) is preferable (Table VI).

According to the HTP for the coldest day (average), January 12 (Figure 8), the lowest temperature recorded outside was $5{ }^{\circ} \mathrm{C}$ at 5 a.m., while the highest recorded temperature was $13.6{ }^{\circ} \mathrm{C}$ at 3 p.m. All models warmed the internal spaces with the highest indoor temperature being recorded at $18{ }^{\circ} \mathrm{C}$ in Model 2 (SC without insulation). Excluding Model 2, the highest recorded indoor temperature was $15.6{ }^{\circ} \mathrm{C}$ in Model 5. Thus, the best is Model 5 (SC with ccSPF), followed by Model 3 (SC with rock wool) and 4 (SC with wool) (Table VII).

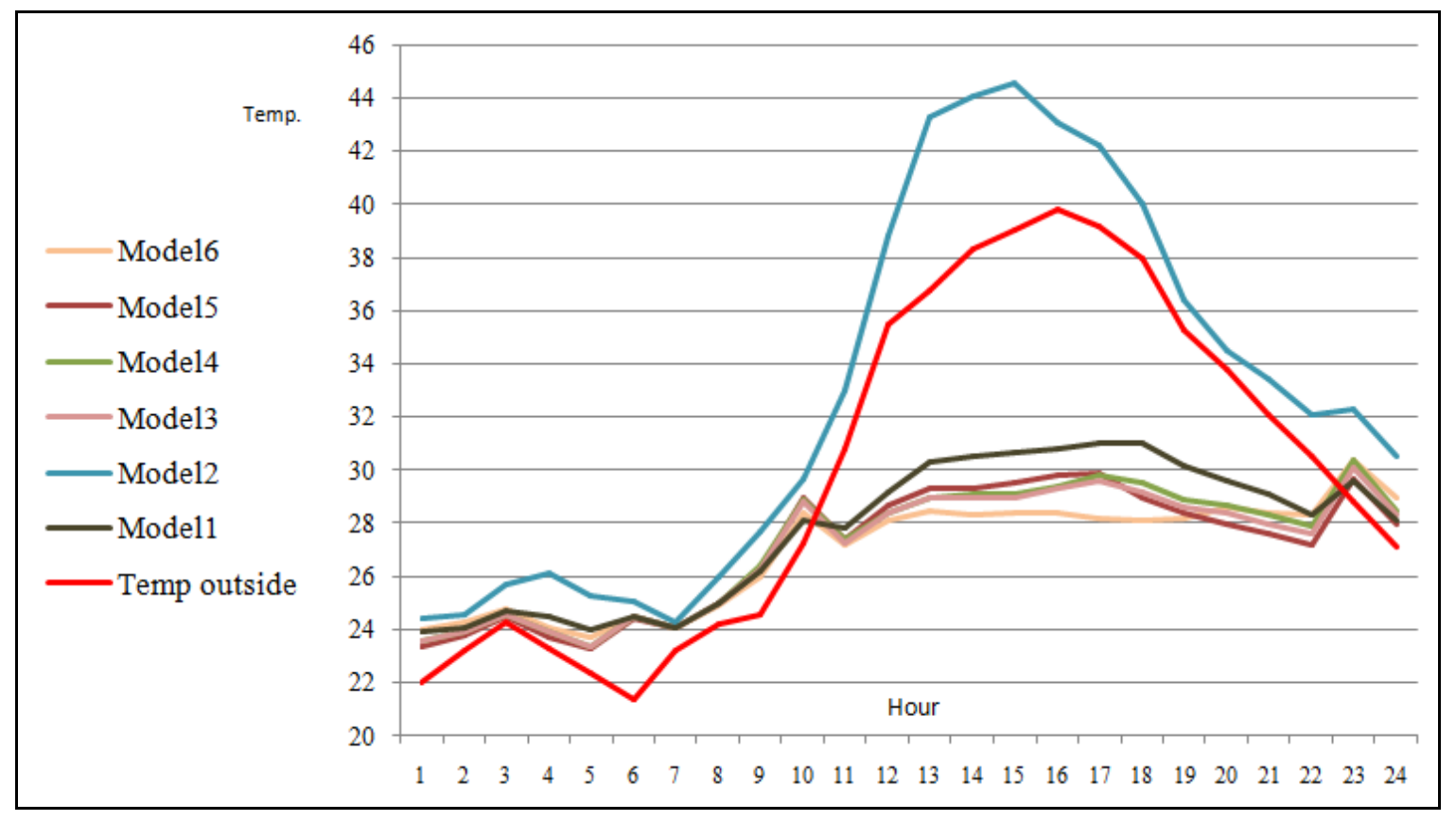

Fig. 7 HTP for the hottest day (average), April 30 
TABLE VI.

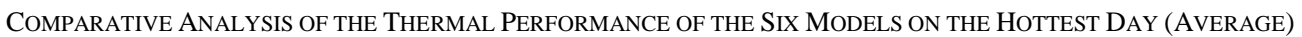

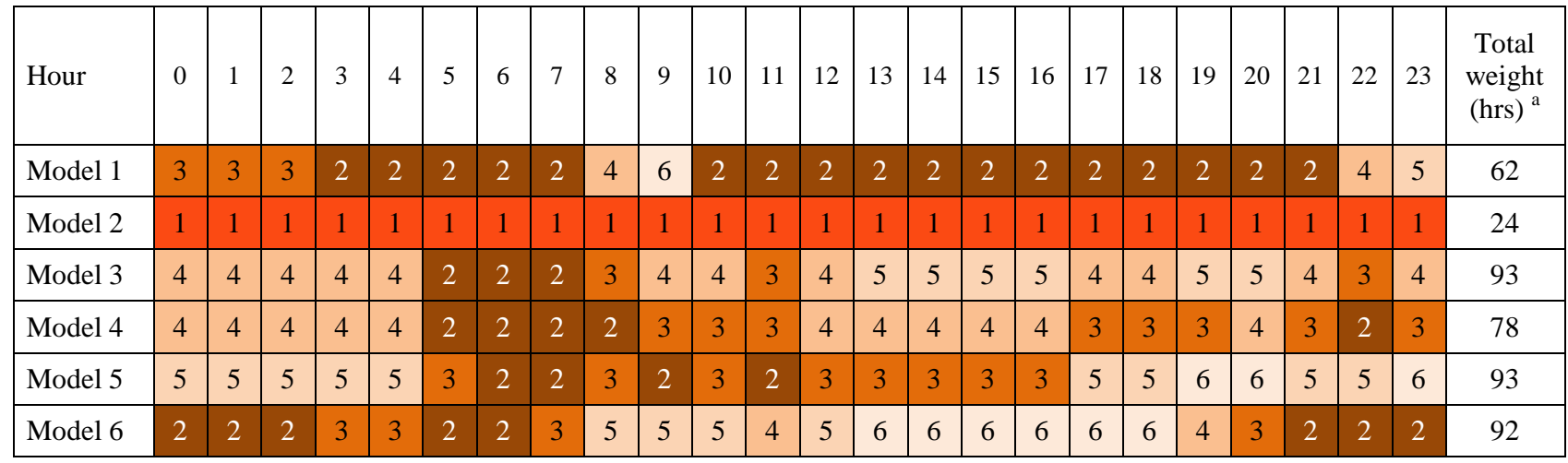

a The six models were weighed from 1 to 6 and arranged from the least efficient thermal insulation model (with the lowest difference between outside and inside temperatures) (weighed 1) to the most efficient model (with the highest difference between outside and inside temperatures) (weighed 5 or 6 ).

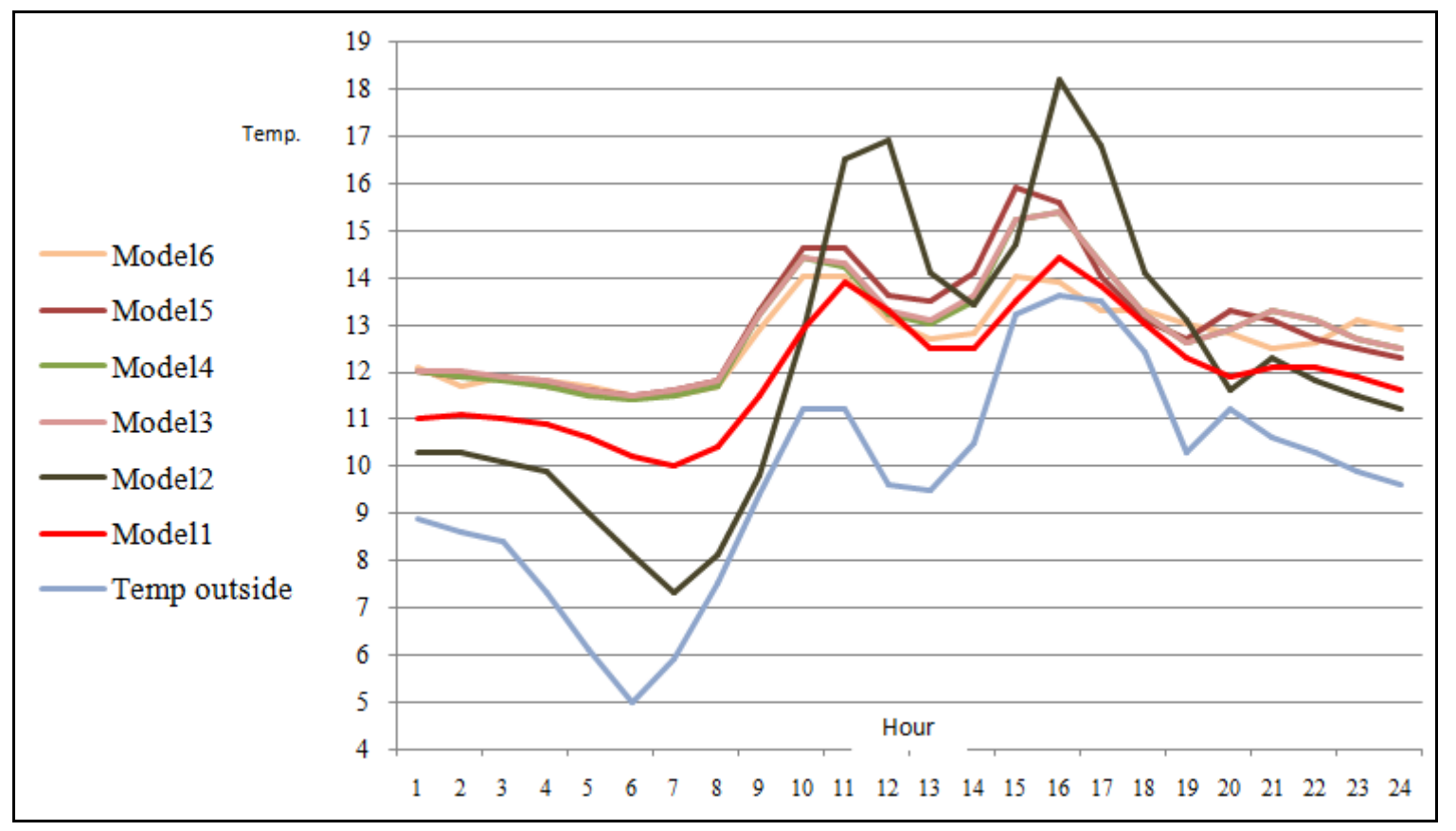

Fig. 8 HTP for the coldest day (average), January 12

TABLE VII.

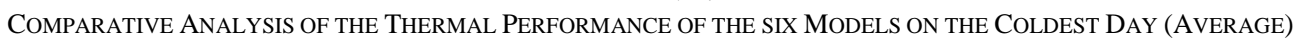

\begin{tabular}{|l|l|l|l|l|l|l|l|l|l|l|l|l|l|l|l|l|l|l|l|l|l|l|l|l|l|l|l|}
\hline Hour & 0 & 1 & 2 & 3 & 4 & 5 & 6 & 7 & 8 & 9 & 10 & 11 & 12 & 13 & 14 & 15 & 16 & 17 & 18 & 19 & 20 & 21 & 22 & 23 & $\begin{array}{c}\text { Teight } \\
\text { (hrs) }\end{array}$ \\
\hline Model 1 & 2 & 2 & 2 & 2 & 2 & 2 & 2 & 2 & 2 & 2 & 1 & 3 & 1 & 1 & 1 & 2 & 2 & 1 & 1 & 2 & 1 & 2 & 2 & 2 & 42 \\
\hline Model 2 & 1 & 1 & 1 & 1 & 1 & 1 & 1 & 1 & 1 & 1 & 6 & 5 & 6 & 3 & 3 & 5 & 5 & 5 & 5 & 1 & 2 & 1 & 1 & 1 & 59 \\
\hline Model 3 & 3 & 5 & 4 & 4 & 4 & 4 & 4 & 4 & 4 & 4 & 4 & 3 & 4 & 5 & 4 & 3 & 4 & 3 & 2 & 4 & 5 & 5 & 4 & 4 & 94 \\
\hline Model 4 & 3 & 4 & 3 & 3 & 3 & 3 & 3 & 3 & 4 & 4 & 3 & 2 & 3 & 4 & 4 & 3 & 4 & 3 & 2 & 4 & 5 & 5 & 4 & 4 & 101 \\
\hline Model 5 & 3 & 4 & 4 & 3 & 4 & 4 & 4 & 4 & 5 & 5 & 5 & 4 & 5 & 6 & 5 & 4 & 3 & 2 & 3 & 5 & 4 & 4 & 3 & 3 & 100 \\
\hline Model 6 & 4 & 3 & 4 & 4 & 5 & 4 & 3 & 3 & 3 & 3 & 2 & 1 & 2 & 2 & 2 & 1 & 1 & 4 & 4 & 3 & 3 & 3 & 5 & 5 & 74 \\
\hline
\end{tabular}

${ }^{\mathrm{b}}$ The six models were weighed from 1 to 6 and arranged from the least efficient thermal insulation model in heating (the lowest difference between outside and inside temperatures) (weighed 1) to the most efficient model in heating (with the highest difference between outside and inside temperatures) (weighed 5 or 6). 


\section{B. Discomfort Loads Hours (DLH)}

Regarding DLH, Model 2 (SC without insulation) has the highest too-hot, the lowest too-cold, and the highest total discomfort hours (Figure 9). It is followed by Model 1 (the conventional building). The optimum model is that with the lowest too-hot and the lowest too-cold discomfort hours. Model 6 (SC with straw) has the lowest too-hot discomfort hours but the highest too-cold discomfort hours among all models, which indicates that it is effective in cooling on hot days but not effective in heating on cold days. Models 3 (SC with rock wool) and 4 (SC with wool) have the lowest too-hot discomfort hours after Model 6 (SC with straw), but in terms of the total discomfort hours, they come after Model 5 (SC with ccSPF). The most reasonable insulation is ccSPF (Model 5), which has the lowest total discomfort hours and a balance between the lowest too-hot and too-cold discomfort hours around the year. Straw has a good cooling effect on hot days but requires the use of a heating system on cool days, which could interfere with its sustainability.

\section{Thermal Lag and U-value}

Thermal lag has been estimated according to the following formula:

$$
t(\text { hrs })=0.53 * \frac{\mathrm{T}}{2} * \in * \sqrt{\frac{\mathrm{ro} * \mathrm{c}}{\text { Jambda } * \mathrm{pi} * \mathrm{~T}}}
$$

$\mathrm{T}=$ the period of external variation in hours (taken for 24 hours)

$\mathrm{e}=$ thickness $(\mathrm{m})$

Ro $=$ density $(\mathrm{kg} / \mathrm{m} 3)$

$\mathrm{C}=$ specific heat $(\mathrm{kJ} / \mathrm{kg} \mathrm{K})$

Lambda $=$ conductivity $(\mathrm{W} / \mathrm{m} \mathrm{K})$

pi $=3.14$

With regard to the thermal lag for the roof, walls, floor, windows, and door of the six models (Table VIII), this paper concludes that Model 2 (SC without insulation) has the lowest thermal lag and the highest U-value regarding the roof and walls. This reflects the poor thermal performance of the uninsulated SC.

The thermal lag of Model 6 (SC with straw) is the highest among all models including the conventional model. Nevertheless, its U-value is not the highest (Table IX). The lowest U-value regarding roof and walls is Model 5 (SC with ccSPF), followed by Model 3 (SC with rock wool). The thermal lag of the floors for all SC models is less than that of the conventional building. This indicates the need for the traditional floor of SCs to be insulated, particularly as SCs have steel cross members.

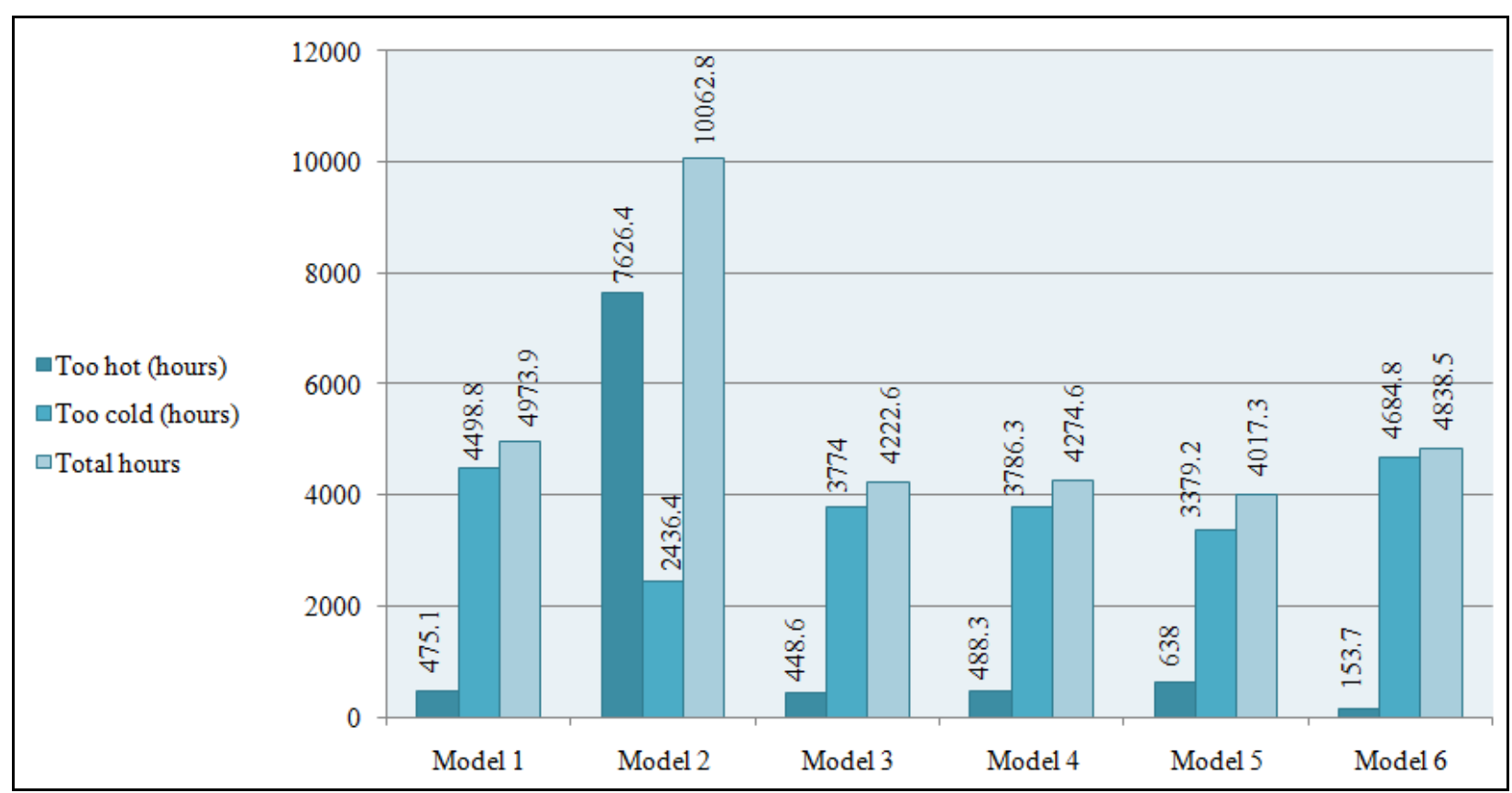

Fig. 9 Total discomfort hours for the six models

TABLE VIII

THERMAL LAG (HRS) FOR THE SIX MODELS

\begin{tabular}{|c|c|c|c|c|c|c|}
\hline & Model 1 & Model 2 & Model 3 & Model 4 & Model 5 & Model 6 \\
\hline Roof & 6.97 & 0.023 & 5.745 & 5.1 & 4.523 & 7.2 \\
\hline Walls & 0.67 & 0.023 & 5.745 & 5.1 & 4.523 & 7.2 \\
\hline Floor & 5.688 & 2.92 & 2.92 & 2.92 & 2.92 & 2.92 \\
\hline Window & 0.189 & 0.189 & 0.189 & 0.189 & 0.189 & 0.189 \\
\hline Door & 0.332 & 0.332 & 0.332 & 0.332 & 0.332 & 0.322 \\
\hline
\end{tabular}


TABLE IX

U-VALUE (W/M².K) FOR THE SIX MODELS

\begin{tabular}{|l|c|c|c|c|c|c|}
\hline & Model 1 & Model 2 & Model 3 & Model 4 & Model 5 & Model 6 \\
\hline Roof & 0.97 & 5.61 & 0.3 & 0.43 & 0.23 & 0.51 \\
\hline Walls & 2.49 & 5.61 & 0.43 & 0.43 & 0.23 & 0.51 \\
\hline Floor & 1.48 & 1.74 & 1.74 & 1.74 & 1.74 & 1.74 \\
\hline Window & 5.44 & 5.44 & 5.44 & 5.44 & 5.44 & 5.44 \\
\hline Door & 2.5 & 2.5 & 2.5 & 2.5 & 2.5 & 2.5 \\
\hline
\end{tabular}

\section{Passive Gain Breakdown PGB Analysis (PGBA)}

Regarding gain from January 1 to December 31 (Figure 10), sol-air is the largest contributor to gain in Model 2 (SC without insulation), followed by Model 1 (brick). Direct solar is the largest contributor to gain in Models 3, 4, 5, and 6, followed by internal. Regarding loss, the largest contributor in all models is external fabric (conduction), followed by ventilation (Figure 11).

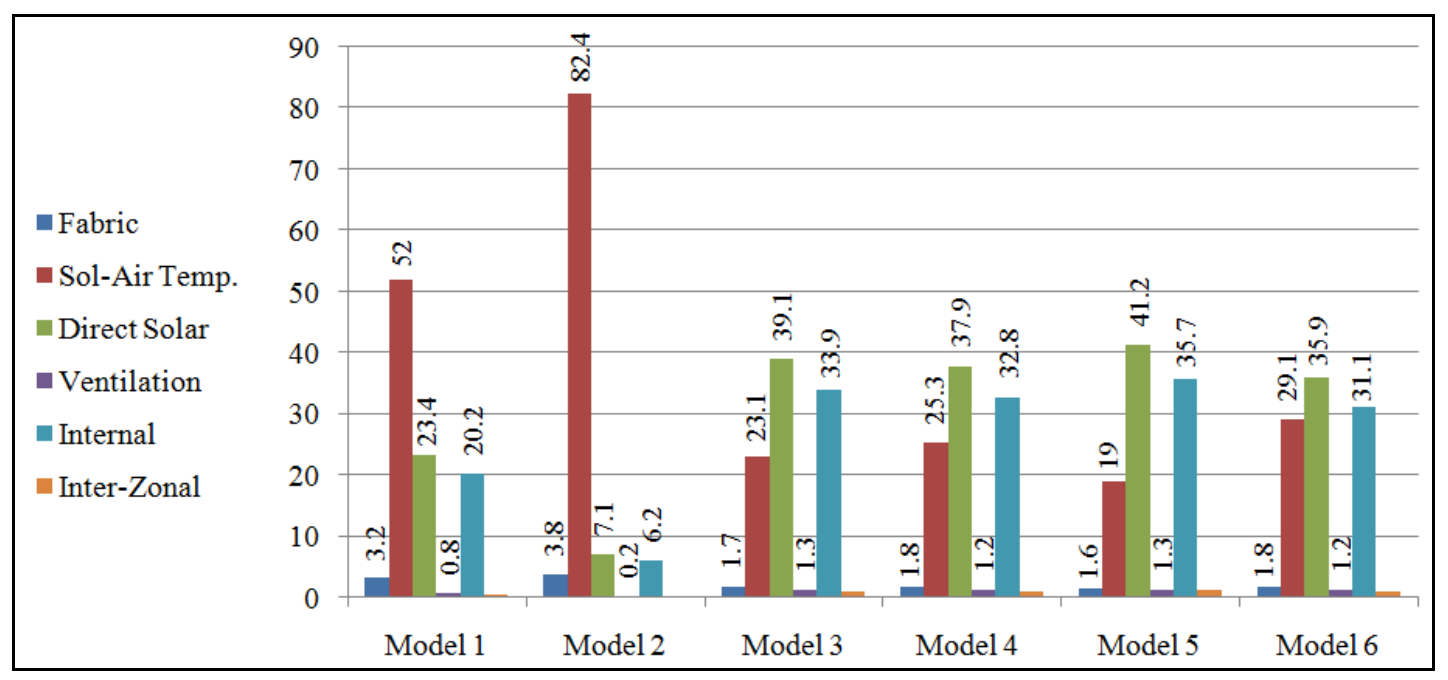

Fig. 10 Comparative PGBA (gain) for the six models

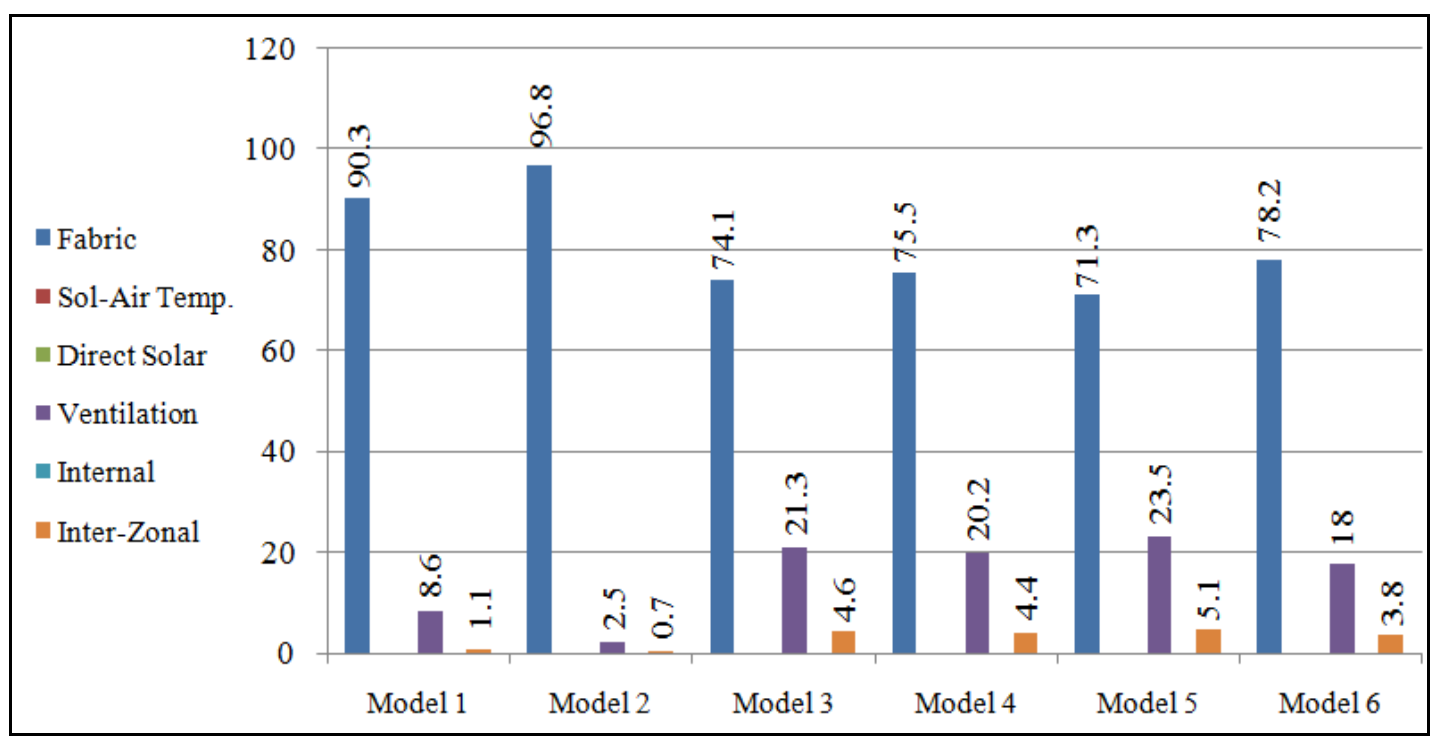

Fig. 11 Comparative PGBA (loss) for the six models

\section{IV.CONCLUSION}

This paper presents a thermal performance analysis of CBBs in Port Said, Egypt, a hot and humid climate. The selection of thermal insulation materials in this study is based on the literature concerning SCA and CBBs. These insulation materials include rock wool and ccSPF in tandem with ecofriendly materials such as wool and straw. All materials are used as external layers with $100 \mathrm{~mm}$ thickness. This paper has conducted a simulation study of six models, including a base model with brick masonry, an SC without insulation, SC with rock wool, an SC with wool, an SC with ccSPF, and an SC with straw. The results of this paper assert that the need for thermal insulation in 
SCs is indispensable for habitation. The most compatible thermal insulation for CBBs in the hot and humid climate of Port Said is ccSPF, which has the lowest total discomfort hours, with a balance between the lowest toohot and too-cold discomfort hours around the year. It is followed by straw, which has a good cooling effect on hot days but requires a heating system on cool days, which could interfere with its sustainability. Augmenting the thermal performance of CBBs, the traditional floor of SCs requires thermal insulation, as do the walls and ceilings, which have steel cross members and air gaps.

Underpinning the reviewed literature regarding the energy requirements and environmental impacts of CBBs is a conflict of judgments, opinions, and results even among those studies based on measurements. This paper suggests significant issues that should be highlighted: Further studies might focus on the financial feasibility and cost effectiveness of a specific CBB, a life cycle assessment of the whole lifespan of a particular $\mathrm{CBB}$, the fundamental or modest changes that occur in the structure of $\mathrm{CBBs}$ as a result of design requirements, and the development of norms to be appended to building codes regarding the construction of $\mathrm{CBBs}$.

\section{REFERENCES}

[1] H. Islam, G. Zhang, S. Setunge, and M. A. Bhuiyan, "Life Cycle Assessment of Shipping Container Home: A Sustainable Construction," Energy and Buildings, vol. 128, pp. 673-685, 2016.

[2] G. Abrasheva, D. Senk, and R. Häußling, "Shipping Containers for a Sustainable Habitat Perspective," Revue de Métallurgie, vol. 109, pp. 381-389, 2012.

[3] L. F. Bernardo, L. A. Oliveira, M. C. Nepomuceno, and J. M. Andrade, "Use of Refurbished Shipping Containers for the Construction of Housing Buildings: Details for the Structural Project," Journal of Civil Engineering and Management, vol. 19, pp. 628-646, 2013.

[4] M. Ismail, K. M. Al-Obaidi, A. M. A. Rahman, and M. I. Ahmad, "Container Architecture in the Hot-Humid Tropics: Potential and Constraints," presented at the International Conference on Environmental Research and Technology (ICERT 2015), Malaysia, 2015.

[5] J. A. Peña and K. Schuzer, "Design of Reusable Emergency Relief Housing Units Using General-Purpose (GP) Shipping Containers," International Journal Of Engineering Research and Innovation, vol. 4, pp. 55-64, 2012.

[6] S. Schiavoni, S. Sambuco, A. Rotili, F. D’Alessandro, and F. Fantauzzi, "A nZEB housing structure derived from end of life containers: Energy, lighting and life cycle assessment," in Building Simulation, 2016, pp. 165-181.

[7] L. D. Garrido, Green Container Architecture 3: Monsa, 2015.

[8] J. D. Smith, "Shipping containers as building components," Master Master, Department of Built Environment, University of Brighton, Unpublished, 2006.

[9] MTS. (2017, April, 1). Port Said Port Authorities. Available: http://www.mts.gov.eg/en/content/28/1-105-Port-Said-PortAuthority

[10] WSC. (2017, April 3). Top 50 World Container Ports. Available: http://www.worldshipping.org/about-the-industry/global-trade/top50-world-container-ports

[11] PSCHC. (2012, April 1). Container Handling Activity. Available: http://www.pscchc.com/getpage1.aspx?pid=11002\&seqid=1

[12] SCCT. (2017, April 2). APM Terminals. Available: http://www.apmterminals.com/en/operations/europe/portsaid/about-us

[13] F. Hosny. (2017, March 27). How 2 Egyptian Entrepreneurs are Building Incredible Houses Out of Abandoned Shipping Containers. Available: http://cairoscene.com/Business/Qubix-EgyptianEntrepreneurs-Building-Incredible-Houses-Shipping-Containers

[14] CWM. (2016, July 2). Qubix. Available: http://www.cairowestmag.com/qubix/
[15] Artdepartment-berlin. (2012, July 2). Container Lounge Hacienda North Coast Egypt Summer. Available: http://www.twotimestwentyfeet.com/en/containerprojects/container-lounge-hacienda-north-coast-egypt-summer2012/

[16] E. L. Alemdağ and Ö. Aydin, "A study of Shipping Containers as a Living Space in Context of Sustainability," Artium, vol. 3, pp. 1729, 2015.

[17] A. W. Botes, "A feasibility Study of Utilising Shipping Containers to Address the Housing Backlog in South Africa," Master, Faculty of Engineering, Civil Department, Construction Management Division, Stellenbosch University, 2013.

[18] J. Vijayalaxmi, "Towards Sustainable Architecture-a Case with Greentainer," Local Environment, vol. 15, pp. 245-259, 2010.

[19] M. Martinez-Garcia. (2014, December 21). Alternative Housing: The Shipping Container Home. Available: https://crt.blogs.realtor.org/files/2014/12/shipping-containerhomes-white-paper-2014-12-10.pdf

[20] B. Pagnotta. (2011, 10 February). The Pros and Cons of Cargo Container Architecture. Available: http://www.archdaily.com/160892/the-pros-and-cons-of-cargocontainer-architecture/

[21] P. Kaveh and A. Mahdavi, "A Performance Comparison of Ordinary and Container Classrooms in Austria," Asian Journal of Civil Engineering (BHRC), vol. 15, pp. 383-390, 2014.

[22] ISBUA. (n.d., February 8). Types of Shipping Containers and ISBU. Available: http://www.isbu-association.org/types-of-shippingcontainers.htm

[23] K. A. Brandt, "Plugging in: Reinterpreting the Traditional Housing Archetype within a Community Using Shipping Containers," Master Master, Faculty of the Graduate School, University of North Carolina at Greensboro, Greensboro, 2011.

[24] K. Giriunas, H. Sezen, and R. B. Dupaix, "Evaluation, Modeling, and Analysis of Shipping Container Building Structures," Engineering Structures, vol. 43, pp. 48-57, 2012.

[25] WHE. (2002, February 22). Shipping Container Architecture. Available:

http://read.schoollibrary.com/articles/eng/Shipping_container_archi tecture

[26] C. Ulloa, M. E. Arce, G. Rey, J. L. Míguez, and J. Hernández, "Recycling COR-TEN® Sea Containers into Service Modules for Military Applications: Thermal Analysis," Energies, vol. 10, p. 820, 2017.

[27] L. D. Garrido, Sustainable Architecture Containers: Monsa, 2011.

[28] P. Olivares and A. Andres, "Sustainability in Prefabricated Architecture: A Comparative Life Cycle Analysis of Container Architecture for Residential Structures," Master Master, Faculty of Architecture and Design, School of Architecture, Victoria University of Wellington, Wellington, New Zealand, 2010.

[29] M. Brodaski, R. Campanelli, and K. Zabinsk, "Shipping Container Emergency Shelters," Worcester Polytechnic Institute, Worcester Polytechnic Institute2010.

[30] RSCPTM. (2013, February 24). Shipping Container Structural Components and Terminology. Available: http://www.residentialshippingcontainerprimer.com/CONTAINER \%20COMPONENTS\%20AND\%20TERMINOLOGY

[31] M. Finnegan. (2015, February 18). The Secret to Laying Successful Foundations for Shipping Containers. Available: http://www.gatewaycontainersales.com.au/the-secret-to-layingsuccessful-foundations-for-shipping-containers/

[32] Tom. (2015, February 18). Shipping Container Home: Foundation Types. Available: http://www.containerhomeplans.org/2015/09/shipping-containerhome-foundation-types/

[33] Tom. (2015, December 29). 5 Methods to Insulate Your Shipping Container Home. Available: http://www.containerhomeplans.org/2015/03/5-methods-toinsulate-your-shipping-container-home/

[34] Tom. (2015, December 29). How Do I Keep My Container Home Cool? Available: http://www.containerhomeplans.org/2015/02/how-do-i-keep-mycontainer-home-cool/

[35] G. Green. (2008, February 18). Greentainer Project in Gandino Italy. Available: http://www.jetsongreen.com/2008/11/greentainerpro.html

[36] Tom. (2015, March 17). How Should You Ventilate Your Shipping Container Home? Available: 
http://www.containerhomeplans.org/2015/04/how-should-youventilate-your-shipping-container-home/

[37] ArchDaily. (2008, July 3). CR Land Guanganmen Green Technology Showroom / Vector Architects. Available: http://www.archdaily.com/9633/cr-land-guanganmen-greentechnology-showroom-vector-architecture/

[38] D. W. Reed, "The Real Way to Add Straw Bales to Containers," ed, 2010.

[39] PremierBox. (2016, July 3). How to Insulate Your Shipping Container. Available: http://premiershippingcontainers.com.au/how-to-insulate-yourshipping-container.html

[40] Solaripedia. (2011, July 3). Cargotecture Brings Cargo Containers Home. $\quad$ Available: http://www.solaripedia.com/13/336/4071/greentainer_pvs_italy.htm 1

[41] K. Rosenfield. (2012, 29 Dec). Vissershok Container Classroom / Tsai Design Studio. Available: http://www.archdaily.com/216867/vissershok-container-classroomtsai-design-studio/

[42] Bruno. (2016, July 3). Off The Grid Earth Cooled Underground Shipping Container Home. Available: http://knifeinhand.com/offthe-grid-earth-cooled-underground-shipping-container-home/
[43] R. Herr. (2013, February 18). Best Insulation Ideas for Shipping Containers. Available: http://containerauction.com/read-news/bestinsulation-ideas-for-shipping-containers

[44] TinCribs. (2016, July 3). Insulating Container Homes. Available: http://www.tincribs.com/insulating-container-homes.htm

[45] RM. (2014, July 3). Insulation Offers Acoustic Properties. Available: http://www.roofingmagazine.com/insulation-offersacoustic-properties/

[46] ArchiExpo. (2017, July 4). Thermal insulation / sheep wool / roll / recyclable :ECOROLL. Available: http://www.archiexpo.com/prod/thermafleece/product-84214992837.html

[47] BIOPASSIVHAUS. (n.d., July 4). Straw as thermal insulation. Available: http://www.biopassivhaus.eu/eng/material_slama.html

[48] Steelss. (2011, March 21). Data Table for:Carbon steel:Corten A. Available: http://www.steelss.com/Carbon-steel/corten-a.html

[49] U. Jarfelt and O. Ramnäs, "Thermal conductivity of polyurethane foam-best performance," in 10th International Symposium on district heating and cooling, 2006, pp. 3-5.

[50] J. Manville. (2015, March 21). Closed-cell Spray Polyurethane Foam. Available: https://www.jm.com/content/dam/jm/global/en/buildinginsulation/Files/BI\%20Data\%20Sheets/BI\%20Canada/CAN339_Corbond_III_EN.pdf 